Soil Science and Agricultural Engineering

http:/www.journals.zu.edu.eg/journalDisplay.aspx?Journalld=1\&queryType=Master

\title{
DEVELOPMENT AND PERFORMANCE EVALUATION OF A NEW PNEUMATIC PRECISION METERING DEVICE FOR PLANTING MEDICINAL AND AROMATIC CROPS
}

\author{
Ola T.E. Ahmad ${ }^{\text {* }}$, M.M. Morad ${ }^{1}$, M.M. Ali ${ }^{1}$ and M.H. Abo-Elnaga ${ }^{2}$ \\ 1. Agric. Eng. Dept., Fac. Agric., Zagazig Univ., Egypt. \\ 2. Agric. Eng. Inst., Agric. Res. Cen., Dokki, Egypt.
}

Received: 12/11/2017 ; Accepted: 28/11/2017

\begin{abstract}
The aim of the present work is to develop a simple and low cost pneumatic metering device to be suitable for planting some medicinal and aromatic seeds (dill and coriander). To fulfill this objective, a developed planter with the pneumatic precision metering device was fabricated and tested in both laboratory and field. The performance of the developed planter was studied under some different operating conditions and compared to the traditional method. Physical and mechanical properties of seeds were investigated to optimize the design of the planters components. The experimental results in laboratory revealed the following: The feeding rate and the application rate of dill and coriander seeds increased with increasing the metering device rotational speed, increasing vacuum tube hole numbers and increasing forward speed. The experimental results in the field revealed the following: The field capacity recorded $(0.20$ and 0.016 fad. $/ \mathrm{hr}$.) and $(0.29$ and $0.025 \mathrm{fad} . /$ hr.) for dill and coriander crops with the developed machine and manual planting respectively. While field efficiency recorded (95.25 and 95.35\%) for dill and coriander crops with the developed planter. At longitudinal direction; the maximum values of coefficient of variation recorded (34.67 and 27.73\%) for dill and coriander crops with manual planting, while the minimum values recorded (11.75 and $5.97 \%$ ) for dill and coriander crops with the developed planter. The highest values of seed yield recorded $(0.317$ and $0.975 \mathrm{Mg} / \mathrm{fad}$.) with the developed planter and manual planting for dill and coriander crops, respectively. The minimum values of consumed energy were (14.21 and 19.99 $\mathrm{kW} . \mathrm{hr}$./fad.) for coriander crop with manual planting and the developed planter. While the maximum values were (22.2 and $28.98 \mathrm{~kW} . \mathrm{hr}$./fad.) for dill crop under the same conditions. The lowest cost per unit of production it recorded $(24.88$ and $73.62 \mathrm{LE} / \mathrm{fad}$.) for dill crop with the developed planter and manual planting, respectively. While with coriander crop it recorded (149.43 and $356.36 \mathrm{LE} / \mathrm{fad}$.) under the same conditions.
\end{abstract}

Key words: Vacuum, pneumatic, precision, dill, coriander, metering, planting.

\section{INTRODUCTION}

The medicinal and aromatic crops are considered one of the most important untraditional agricultural commodities which can be used as a base for Egyptian national income development. The two main medicinal and aromatic crops are coriander (Sativum coriandrum) and dill (Anethum graveolinus L.). The cultivated area of these crops in Egypt reach

* Corresponding author: Tel. : +201065727293

E-mail address: ola_taha2011@yahoo.com up to 80000 Faddans (FAO Statistical Year Book, 2017).

Several types of metering devices are used for precision planters such as: a vacuum disk type, an inclined plate type, a belt type, a vertical rotor type, and a roller type. The roller metering device type is used most widely in the mechanized seeding of crops. It is generally known that the scattering of seeds is caused mainly by the improper design of the metering 
device and seed tube. The effect of constructional properties (roll length, diameter, etc.) and operational variables (seed rate, travel speed, and seed spacing) on the flow metering device must be investigated. These include the produced vacuum pressure, physical and mechanical properties of seeds, the design feature of the metering mechanisms, seed quality, soil conditions, the skill of the operator and the operational conditions .

Shaaban (2010) tested a vacuum precision seeder prototype suitable for onion seeds and developed a mathematical model for predicting the optimum vacuum pressure of a precision vacuum seeder using onion seed properties, vacuum characteristics and the hole geometry of the seed plate. The precision vacuum seeder prototype was tested under four blower speeds, three seed plates with different hole diameters, four speeds of seed plate and three forward speeds. Soil bin and field tests showed that the most favorable conditions in terms of operating developed precision vacuum seeder will be 0.21 $\mathrm{m} / \mathrm{s}$ disc speed at $4500 \mathrm{rpm}$ blower speed with the seed plate of $1.0 \mathrm{~mm}$ hole diameter at 3.6 $\mathrm{km} / \mathrm{hr}$., forward speed for planting onion seeds under Egyptian conditions.

Karayel and Ozmerzi (2002) studied the effect of different forward speeds of hill dropping for some vegetable seeds using the seed metering unit of a precision vacuum seeder. They found that the coefficients of variation of hill distance and seed number in hill increased as forward speed increased for both seeds. The most suitable forward speed was $0.5 \mathrm{~m} / \mathrm{sec}$. Scattering distance ratios of forward speed 0.5 and $1.0 \mathrm{~m} / \mathrm{sec}$., were about 20 to $30 \%$.

Kamel et al. (2003) investigated the effect of some operating factors on the uniformity of seeds distribution by using pneumatic seed drill comparing with mechanical seed drill at five different forward speeds after three levels of land preparation. The longitudinal and lateral scattering increased as the forward speed increased for both of the two drill seeders. The longitudinal and lateral scattering values ranged from 1.54 to $5.69 \mathrm{~cm}$ and from 0.18 to $2.85 \mathrm{~cm}$, when the forward speed ranged from 0.56 to $2.34 \mathrm{~m} / \mathrm{sec}$, respectively under different land preparation levels.
Morad et al. (2010) showed that there was an inverse relationship between machine forward speed and emergence ratio. Increasing forward speed from 2.5 to $3.88 \mathrm{Km} / \mathrm{hr}$., decreased emergence ratios from 92 to $88.2 \%$ and from 89 to $83.7 \%$ under 20 and $30 \mathrm{~cm}$ distance between plants in a row, respectively. The decrease in emergence ratio by increasing forward dispersion at high speeds resulting in low emergence ratio.

Adisa (2012) referred to crops usually planted using precision seed metering devices include most horticultural crops and maize, sorghum, sunflower, and beans. Typically, precision seed metering systems are used on what are generally as 'row crop' planters.

Locally, micro-seed crops lack planting machines, for this reason, such care had to be taken to design, develop and operate medicinal and aromatic crops planting machines with an accurate scientific guidance taking into consideration machine efficiency, seed uniformity, durability, energy, and cost requirements.

So, the objectives of this work are to:

1. Develop a pneumatic simple precision metering device from low cost and local material.

2. Estimate some different operating parameters affecting the performance of the developed seed metering device.

3. Fabricate a local planter with the precision metering device to be suitable for planting some medicinal and aromatic seeds.

4. Evaluate the developed planter from the economic point of view.

\section{MATERIALS AND METHODS}

This work aimed essentially to develop a simple and low-cost pneumatic precision metering device to suit planting some medicinal and aromatic seeds (dill and coriander) with a vacuum tube metering device by air suction. To fulfill this objective, a developed planter with the pneumatic precision metering device was fabricated in a local workshop at Meet - Ali Dakahleia Governorate. 


\section{Materials}

\section{The used crops}

Two medicinal and aromatic seeds (dill and coriander) were used. The physical and mechanical properties of these crops were showed in Table 1.

\section{The developed planter}

The developed planter was designed specifically for this work and was constructed at a private work shop in Dakahleia Governorate. The main dimensions of the developed planter are tabulated in Table 2 and Fig. 1.

The developed planter consists of the following main parts:

\section{The frame}

The frame was made of Beam Steel Ushaped of $12 \times 6 \mathrm{~cm}$ with $105 \mathrm{~cm}$ of length, 50 $\mathrm{cm}$ of width and $76 \mathrm{~cm}$ of high, It was supported by three hitch points to suspension the planter behind the tractor. The frame is carried and fixed on the axial steel with two rubber wheels at a diameter of $50 \mathrm{~cm}$. At the end of the frame, two steel rods at length of $80 \mathrm{~cm}$ were fixed with two furrow openers and cover wheel at a diameter of $20 \mathrm{~cm}$ and length of $25 \mathrm{~cm}$. The steel rods can be adjusted at a suitable distance.

\section{The seed hopper}

The seed hopper is simple built and made of galvanized thin sheet iron $(1 \mathrm{~mm})$ thick, the bottom side of seed hopper represent the form of a rectangular at dimensions of $95 \times 15 \mathrm{~cm}$, The front side of the seed hopper was formed as a rectangular at dimensions of $95 \times 20 \mathrm{~cm}$ at a vertical position, while the rear side of the seed hopper as represented a rectangular at dimensions of $95 \times 25 \mathrm{~cm}$ at a slope angle of 135 degrees, the upper side of the seed hopper represent the cover at dimensions of $95 \times 30 \mathrm{~cm}$, the inside size of seed hopper is divided into two sections by one barrey. The rear side of the seed hopper has two gates to deliver seeds. The funnel of plastic sheet was connected with a plastic tube to drop the seeds in the soil furrow.

\section{The feeding device}

The feeding device (A vacuum tube metering device) was made of aluminum tube at length of
$65 \mathrm{~cm}$, diameter of $5.08 \mathrm{~cm}$ and thick of $0.1 \mathrm{~cm}$. At the tube perimeter, there are holes at diameters of 2 and $3 \mathrm{~mm}$ that are arranged as a circle form to be suitable for dill and coriander seeds. Also, a drum steel rod with a rubber lining at length of $50 \mathrm{~cm}$ and diameter of $2 \mathrm{~cm}$ was installed inside the feeding tube and touching the surface from the inside toward the gate out of delivering seeds to prevent air to permit seeds to flow out. The feeding device is fixed with two silicon bases at the bottom of seed hopper, one side of the tube is connected with suction engine by a plastic tube at diameter of $4.5 \mathrm{~cm}$ and length of $65 \mathrm{~cm}$ while, the other side is fixed with steel shaft at diameter of 2.5 $\mathrm{cm}$ with transmission gears at different teeth numbers of 15,18 and 22 and the ground wheel by gear of 61 teeth.

\section{Power source}

Four-wheel tractor (Kubota V 1702 - DI-A) $34 \mathrm{HP}(25.4 \mathrm{~kW})$ Diesel engine was used in this study for operating the developed planter.

\section{Vacuum cleaner motor}

Vacuum cleaner motor was used for operating the feeding device with the following specifications (Table 3).

\section{Power inverter}

Power inverter was used to transform the battery capacity of 12 volts DC to 220 volts AC ability to operate the vacuum cleaner motor.

\section{Methods}

The experiments were divided into two separated parts: the first part was conducted in the laboratory under control conditions, while the second part was carried out in the field through two successful agricultural seasons of 2016 and 2017.

\section{Laboratory Tests}

\section{Experimental conditions of laboratory tests}

Laboratory tests were conducted under the following conditions:

- Rotational speed of a vacuum tube of the metering device was varied as the following (15, 18 and $21 \mathrm{rpm}),(29,35$ and $42 \mathrm{rpm})$ and (32, 40 and $48 \mathrm{rpm})$, respectively, under gears teeth numbers (15, 18 and 22 teeth). 
Table 1. Physical and mechanical properties of dill and coriander seeds

\begin{tabular}{|c|c|c|c|}
\hline & \multirow[t]{2}{*}{ Property } & \multicolumn{2}{|c|}{ Seeds } \\
\hline & & Dill & Coriander \\
\hline \multirow{15}{*}{ 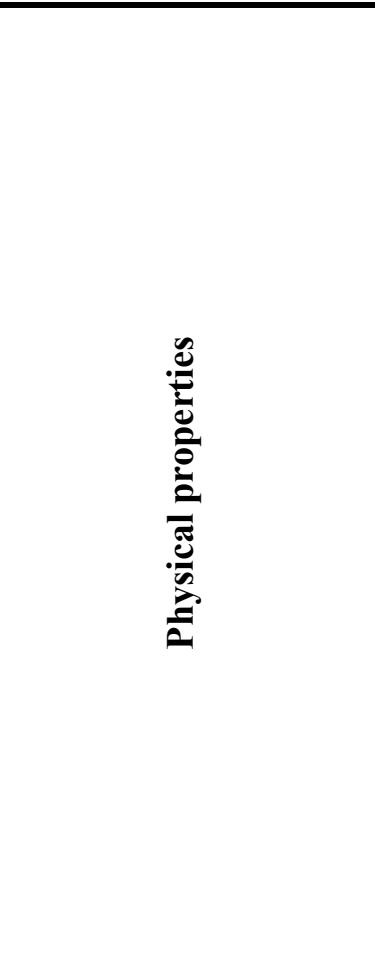 } & Length, mm & 3.88 & ------- \\
\hline & Width, mm & 1.84 & ------- \\
\hline & Thickness, mm & 1.2 & ------- \\
\hline & Dimensions(Major), mm & ------- & 4.03 \\
\hline & Dimensions(Medium), mm & ------- & 3.42 \\
\hline & Dimensions(Minor), mm & ------- & 3.11 \\
\hline & Mass of 1000 seeds, $g$ & 3.18 & 8.60 \\
\hline & Seed moisture content $(\%)$ & 5.53 & 5.85 \\
\hline & Volume, $\mathbf{m m}^{3}$ & 8.57 & 19.56 \\
\hline & Arithmetic diameter, mm & 2.30 & ------ \\
\hline & Geometric diameter, mm & 2.85 & 3.49 \\
\hline & Surface area, $\mathbf{m m}^{3}$ & 25.52 & 35.20 \\
\hline & Sphericity (\%) & 0.74 & 86.65 \\
\hline & Seed bulk density, $\mathrm{g} / \mathrm{cm}^{3}$ & 0.432 & 0.290 \\
\hline & Porosity (\%) & 61.88 & 63.84 \\
\hline \multirow{2}{*}{ Mechanical properties } & Coefficient of friction & 0.43 & 0.86 \\
\hline & Angle of repose $\left(^{0}\right)$ & 31 & 28 \\
\hline
\end{tabular}

Table 2. The main dimensions of the developed planter

\begin{tabular}{lc}
\hline Item & Value \\
\hline Total length & $135 \mathrm{~cm}$ \\
Total width & $70 \mathrm{~cm}$ \\
Total height & $100 \mathrm{~cm}$ \\
Total mass & $87.6 \mathrm{~kg}$ \\
\hline
\end{tabular}




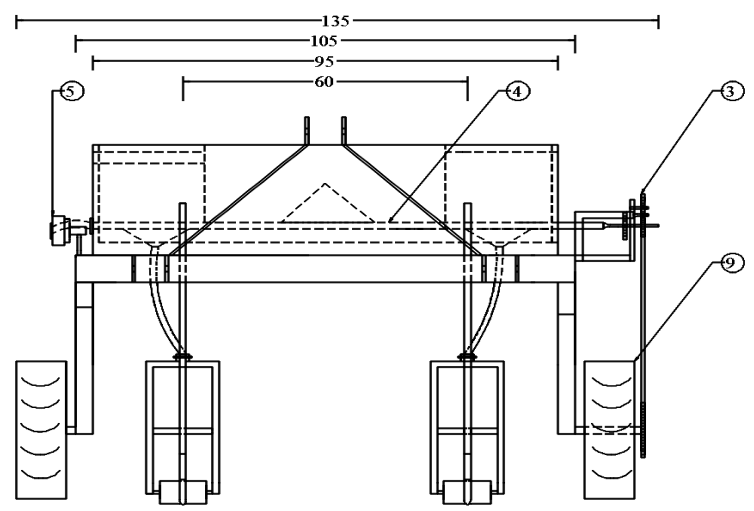

Elevation view

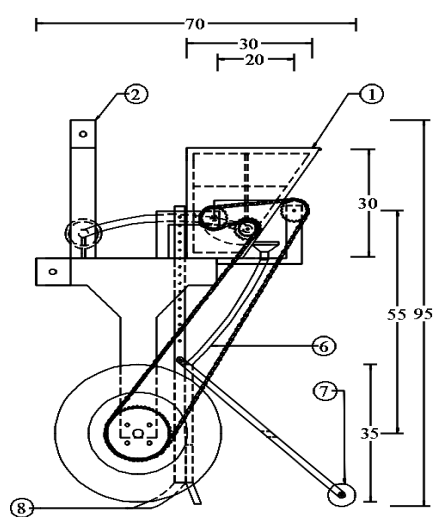

Side view

Dimensions in mm.

\begin{tabular}{clclcl}
\hline No. & Part name & No. & Part name & No. & Part name \\
\hline 1 & Seed hopper & 2 & Hitch points & 3 & Gear \\
4 & Feeding device & 5 & Vacuum cleaner motor & 6 & Planting tube \\
7 & Seed covering wheel & 8 & Runner opener & 9 & Land wheal \\
\hline
\end{tabular}

Fig. 1. Elevation and side view of the developed planter

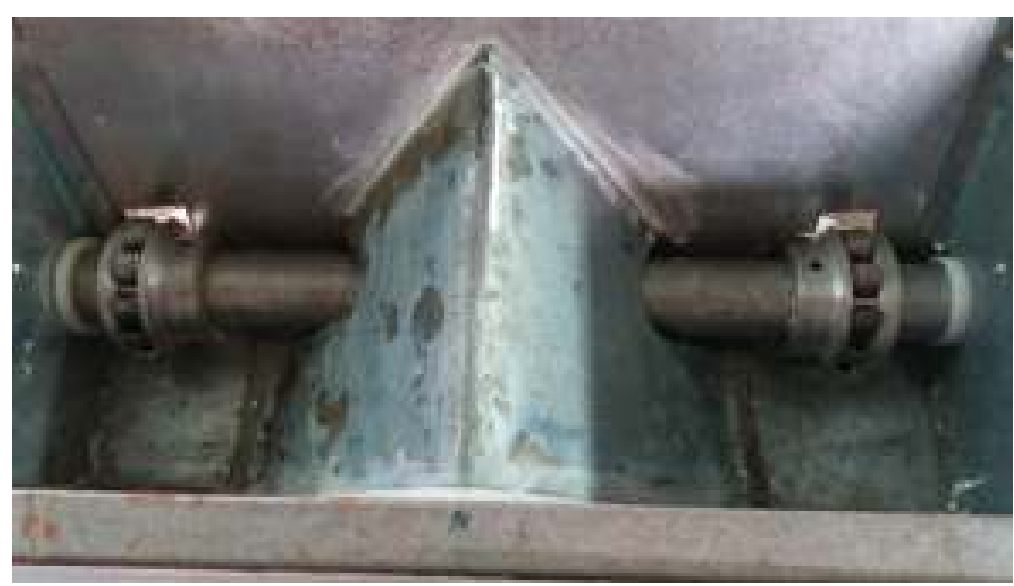

Fig. 2. Photo of the feeding device

Table 3. The main specifications of the used vacuum cleaner motor

\begin{tabular}{lc}
\hline Item & Value \\
\hline Model & Class B \\
Current intensity & $6.36 \mathrm{~A}$ \\
Electrical capacity & $1400 \mathrm{~W}$ \\
Electrical power & $220 \mathrm{~V}$ \\
RPM & 32000 \\
Electrical frequency & $50 / 60 \mathrm{HZ}$ \\
\hline
\end{tabular}


- Forward speeds of $(0.65,1.03$ and 1.45 $\mathrm{km} / \mathrm{hr}$.).

- The vacuum tube holes numbers were adjusted as the following; (14, 19 and 28 holes per row).

According to preliminary experiments air stream velocity inside a vacuum tube metering device was kept constant and adjusted at 0.1 and $0.2 \mathrm{~m} / \mathrm{sec}$., for dill and coriander, respectively.

Before the field experiments, the machine was calibrated in the laboratory by the way of collecting the delivered seeds at different vacum tube rotational speeds and hole number to limit seeds feeding rate in $\mathrm{kg} / \mathrm{hr}$., and application rate in $\mathrm{kg} / \mathrm{fad}$.

\section{Measurements of laboratory tests}

The delivered seeds were collected during on certain duration at different vacum tube rotational speeds and different vacum tube hole numbers and weighed for measuring seed feeding rate in $\mathrm{kg} / \mathrm{hr}$., and application rate in $\mathrm{kg} /$ fad.

\section{Field Experiments}

Filed experiments were carried out to evaluate the developed planter compared to the manual planting during sowing dill and coriander crops. Depending on laboratory tests, filed experiments were conducted under constant forward speed of $1.45 \mathrm{~km} / \mathrm{hr}$., constant vacum tube hole number of 14 and rotational speed of $32 \mathrm{rpm}$.

\section{Dill and coriander experiments}

The dill and coriander balady variety was used in the field experiment. For both of dill and coriander crops, the experimental area was about 0.5 faddan divided into 6 equal plots having dimensions of $60 \times 5.8 \mathrm{~m}$ per each. Two treatments namely, A (Mechanical planting by the developed machine) and B (Manual planting) were carried out and replicated three times in a completely randomized block design. The feeding rate of seeds was $2 \mathrm{~kg} / \mathrm{fad}$., for mechanical sowing and $2.5 \mathrm{~kg} /$ fad., for the manual planting while they were 6 and $7.5 \mathrm{~kg} /$ fad., for coriander and mechanical sowing and manual planting, respectively.
Measurements of Field Experiments

\section{Plant characteristics}

- Average germination ratio.

- Average number of plants per $\mathrm{m}^{2}$ (plant population).

- Average uniformity of plants distribution.

- Average weight of fresh plant (dill) per $\mathrm{m}^{2}$ and per faddan.

- Average weight of seed yield (dill and coriander) per $\mathrm{m}^{2}$ and per faddan.

\section{Uniformity of plant distribution}

The uniformity of plant distribution was measured by using the following method. Deviation in the longitudinal direction from average number of plants at a standard length of 2 meters, the deviation of the plant from average number of the plant at a standard length of 2 meters was estimated according to the following equation:

$$
\mathrm{CV}=\frac{\sigma_{\mathrm{n}-1}}{\overline{\mathrm{x}}} \times 100
$$

Where:

$\mathrm{CV}=$ Coefficient of variation in the longitudinal direction from average number of the plant at standard unit length.

$$
\sigma_{n-1}=\sqrt{\frac{\sum x^{2}-\frac{\left(\sum x\right)^{2}}{n}}{n-1}}
$$

Where:

$\sigma_{\mathrm{n}-1}=$ standard deviation, $\Sigma \mathrm{x}=$ Summation of the number of plants on the longitudinal direction, $\Sigma \mathrm{x}^{2}=$ Summation of a square number of plants on the longitudinal direction, $\bar{X}=$ Average number of the plants at standard length, and $\mathrm{n}=$ Number of reading.

The coefficient of variation under $10 \%$ is considered excellent and with values under $20 \%$ generally considered acceptable for must field application as reported by Coates (1992).

\section{Field capacity and field efficiency}

The theoretical field capacity of the sowing machine is the rate of field coverage. This will be obtained if the machine performed $100 \%$ of 
the time at the rated forward speed. It was determined from the following formula:

$$
\mathrm{P}_{\mathrm{th}}=\frac{\mathrm{S} \times \mathrm{W}}{4200}
$$

Where:

$\mathrm{P}_{\mathrm{th}}=$ Theoretical productively of the machine, (fad./ hr.), $\mathrm{S}=$ Travel speed, (m/hr.), and $\mathrm{W}=$ Rated width (m).

The effective field capacity is the actual average rate of field coverage by the amount of actual time (lost time + productive time) consumed in the operation. It can be determined from the following equation.

Where:

$$
P_{\text {act }}=\frac{60}{T_{u}+T_{i}}
$$

$\mathrm{P}_{\mathrm{act}}=$ The actual field capacity of the machine, (fad./ hr.), $\mathrm{T}_{\mathrm{u}}=$ The utilized time per fad., in minutes, $T_{i}=$ The summation of time lost per fad., in minutes.

The field efficiency of the machine $\left(\eta_{\mathrm{f}}\right)$ is calculated by using the following formula:

$$
\eta_{\mathrm{f}}=\frac{\mathrm{P}_{\mathrm{act}}}{\mathrm{P}_{\mathrm{th}}} \times 100
$$

\section{Human energy}

For each operation, the consumed human energy (EH), was estimated based on the power of one laborer, which considered to be about $0.0746 \mathrm{~kW}(0.1 \mathrm{hp})$ (Megbowon and Adewunmi, 2002). Number of workers in the manual methods was 8 workers, and number of workers in Mechanical planting by developed machine was 1 worker. Human energy can be calculated as follows:

$$
\mathrm{E}_{\mathrm{H}}=\frac{\mathrm{N}_{\mathrm{L}} \times 0.074}{\mathrm{P}_{\mathrm{act}}}
$$

Where:

$\mathrm{E}_{\mathrm{H}}=$ human energy, (kW.hr./fad.), $\mathrm{N}_{\mathrm{L}}=$ number of laborers, (man), and $\mathrm{P}_{\text {act }}=$ Actual field capacity, (fad./hr.).

\section{Mechanicals energy}

Estimation of the required engine power (EP) for the different mechanical sowing treatments was carried out accurately by measuring the decrease in gasoline level in the fuel tank immediately after executing each sowing operation (Hunt, 1983):

$$
\mathrm{E}_{\mathrm{p}}=\frac{\mathrm{F} \cdot \mathrm{c}_{\mathrm{h}}}{3600} \times \mathrm{P}_{\mathrm{f}} \times \mathrm{LCV} \times 427 \times \eta_{\mathrm{th}} \times \eta_{\mathrm{m}} \times \frac{1}{75} \times \frac{1}{1.36}
$$

Where:

$E_{p}=$ Required engine power, $(k W), F \cdot c_{h}=$ Fuel consumption rate (lit/hr.), $\mathrm{P}_{\mathrm{f}}=$ the density of fuel $(\mathrm{kg} / \mathrm{lit})(0.85$ and $0.73 \mathrm{~kg} / \mathrm{l}$ for diesel and gasoline fuel, respectively), $\mathrm{LCV}=$ the lower calorific value of fuel (k.cal $/ \mathrm{kg})$, mean LCV of solar is $10000 \mathrm{k.cal} / \mathrm{kg}, \quad \eta_{\text {th }}=$ the thermal efficiency of the engine, considered to be about 40 and $25 \%$ for diesel and gasoline respect, 427 $=$ thermo-mechanical equivalent, $(\mathrm{kg} \cdot \mathrm{m} / \mathrm{kcal})$, and $\eta_{\mathrm{m}}=$ the mechanical efficiency of the engine, consider to be $80 \%$ for diesel and gasoline engine.

$$
\mathrm{E}_{\mathrm{p}}=3.16 \mathrm{~F} \cdot \mathrm{c}_{\mathrm{h}} \quad \mathrm{kW} .
$$

The engine energy required for each sowing treatment was calculated by using the following equation (Hunt, 1983):

$$
\text { Mechanical energy (kW.hr./fad. })=\frac{\mathrm{E}_{\mathrm{p}}(\mathrm{kW})}{\mathrm{P}_{\text {act }}(\mathrm{fad} . / \mathrm{hr} .)}
$$

\section{Total demand energy}

Total demand energy was calculated as follows:

Total demand energy $(\mathrm{kw} \cdot \mathrm{h} / \mathrm{fed})=$ Human energy + Mechanicals energy.

\section{Cost analysis}

The machine hourly cost was calculated according to the conventional method of estimating both fixed and variable costs (Hunt, 1983).

The operational cost was calculated as follows:

$$
\begin{aligned}
& \text { Operational cost }(\mathrm{LE} / \mathrm{fad} .)= \\
& \frac{\text { Machine hourly cost }(\mathrm{LE} / \mathrm{hr} .)}{\text { Field capacity }(\mathrm{fad} . / \mathrm{hr} .)}
\end{aligned}
$$

Cost per unit of production was calculated as follows:

Cost per unit of production $(\mathrm{LE} / \mathrm{Mg})=$

Operational cost (LE/fad.)

Crop yield (Mg/fad.) 


\section{RESULTS AND DISCUSSION}

The obtained results under laboratory experiments were discussed under the following topics:

\section{Laboratory Results}

\section{Effect of some operating parameters on dill seeds feeding rate}

Fig. 3 shows the effect of different hole number in a vacuum tube metering on the feeding rate of dill seeds under the different rotational speeds of a vacuum tube metering device and forward speeds. The results indicated that, the feeding rate of dill seeds increased from 0.076 to 0.153 , from 0.095 to 0.19 and from 0.114 to $0.228 \mathrm{~kg} / \mathrm{hr}$., by increasing of hole number in a vacuum tube metering device from 14 to 28 holes at constant forward speed of 0.65 $\mathrm{km} / \mathrm{hr}$., and different rotational speed of a vacuum tube metering device of 15,18 and 21 rpm., respectively. While, Fig. 3 showed that, the feeding rate of dill seeds increased from 0.123 to 0.246 , from 0.151 to 0.302 and from 0.187 to $0.362 \mathrm{~kg} / \mathrm{hr}$., at different rotational speeds of a vacuum tube metering device of 29 , 35 and $42 \mathrm{rpm}$. under the same previous values of hole number in a vacuum tube metering device at forward speed of $1.03 \mathrm{~km} / \mathrm{hr}$. Too, Fig. 3 showed that the feeding rate of dill seeds increased from, 0.173 to 0.346 , from 0.212 to 0.424 and from 0.254 to $0.509 \mathrm{~kg} / \mathrm{hr}$., under rotational speed of a vacuum tube metering device of 32, 40 and $48 \mathrm{rpm}$., the same previous values of hole number in a vacuum tube metering device at forward speed of $1.45 \mathrm{~km} / \mathrm{hr}$.

Data analysis confirmed the presence of a strong relationship between the holes numbers in a vacuum tube metering device and feeding rate of dill seeds. The increase in feeding rate is due to the increase in the hole number and the number of times of rotation of the vacuum tube in the time unit.

\section{Effect of some operating parameters on the application rate of dill seeds}

Fig. 4 shows the effect of different rotational speeds of a vacuum tube metering device and different hole number of a vacuum tube metering device on the application rate of dill seeds at forward speed of $0.65 \mathrm{~km} / \mathrm{hr}$. The results indicated that, the application rate of dill seeds increased from 0.890 to 1.340 , from 1.208 to 1.806 , from 1.784 to 2.660 , from 2.098 to 3.146, from 2.674 to 4.000 and from 3.882 to $5.806 \mathrm{~kg} / \mathrm{fad}$., by increasing vacuum tube rotational speed from 15 to $21 \mathrm{rpm}$ under hole number of 14, 19, 28, 33, 42 and 61 holes, respectively. While, at forward speed of 1.03 $\mathrm{km} / \mathrm{hr}$., Fig. 4 indicated that, by increasing vacuum tube rotational speed from 29 to $42 \mathrm{rpm}$ the application rate of dill seeds increased from 1.432 to 2.108 , from 1.784 to 2.864 , from 1.948 to 4.222 , from 2.098 to 4.972 , from 2.674 to 6.330 and from 3.882 to $9.594 \mathrm{~kg} /$ fad., under the same previous conditions. Too, at forward speed of $1.45 \mathrm{~km} / \mathrm{hr}$., Fig. 4 showed that by increasing vacuum tube rotational speed from 32 to $48 \mathrm{rpm}$ the application rate of dill seeds increased from 2.016 to 2.964 , from 2.736 to 4.024 , from 4.032 to 5.932 , from 4.752 to 6.988 , from 6.048 to 8.896 and from 8.784 to $12.920 \mathrm{~kg} /$ fad., under the same previous conditions.

\section{Effect of some operating parameters on} coriander seeds feeding rate

Fig. 5 shows the effects of different vacuum tube hole number on the feeding rate of coriander seeds under different rotational speeds of the vacuum tube metering device and different forward speeds. The results indicated that, the feeding rate of coriander seeds increased from 0.209 to 0.419 , from 0.257 to 0.514 and from 0.308 to $0.617 \mathrm{~kg} / \mathrm{hr}$., by increasing hole number of vacuum tube metering device from 14 to 28 holes at forward speed of $0.65 \mathrm{~km} / \mathrm{hr}$., and different rotational speeds of vacuum tube metering device of 15 , 18 and $21 \mathrm{rpm}$., respectively. While, Fig. 5 at forward speed of $1.03 \mathrm{~km} / \mathrm{hr}$., and the same previous values of hole number of vacuum tube metering device, the results showed an increase in the feeding rate of coriander seeds from 0.332 to 0.666 , from 0.409 to 0.817 and from 0.489 to $0.979 \mathrm{~kg} / \mathrm{hr}$., at different rotational speeds of vacuum tube metering device of 29,35 and 42 rpm., respectively. Too, Fig. 5 at forward speed of $1.45 \mathrm{~km} / \mathrm{hr}$., and the same previous values of hole number of vacuum tube metering device, the results showed an increase in the feed rate of coriander seeds from, 0.467 to 0.935 , from 0.573 to 1.146 and from 0.687 to $1.376 \mathrm{~kg} / \mathrm{hr}$., under rotational speed of vacuum tube metering device of 32, 40 and 48 rpm., respectively.

Data analysis confirmed the presence of a strong relationship between the hole number of a vacuum tube metering device and feeding rate of coriander seeds. The increase in feeding rate is due to the increase in the hole number and the numbers of times of rotation of the feed tube in the time unit.

Effect of some operating parameters on the application rate of coriander

Fig. 6 shows the effect of different rotational speeds of a vacuum tube metering device and 


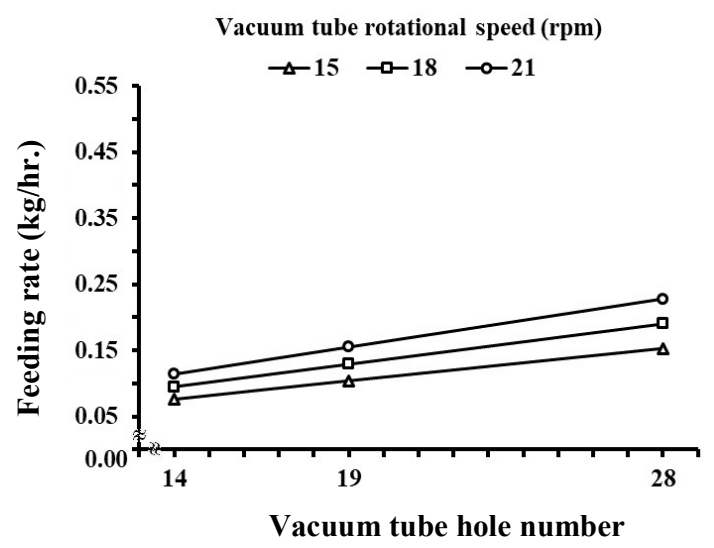

at forward speed of $0.65 \mathrm{~km} / \mathrm{hr}$.

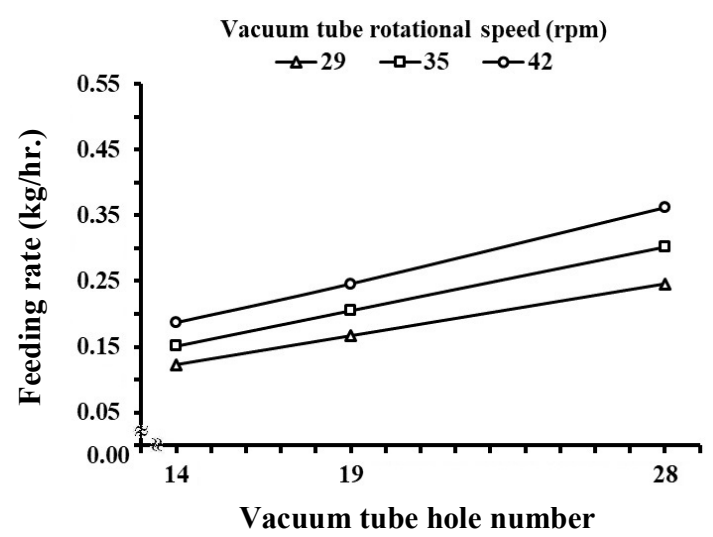

at forward speed of $1.03 \mathrm{~km} / \mathrm{hr}$.

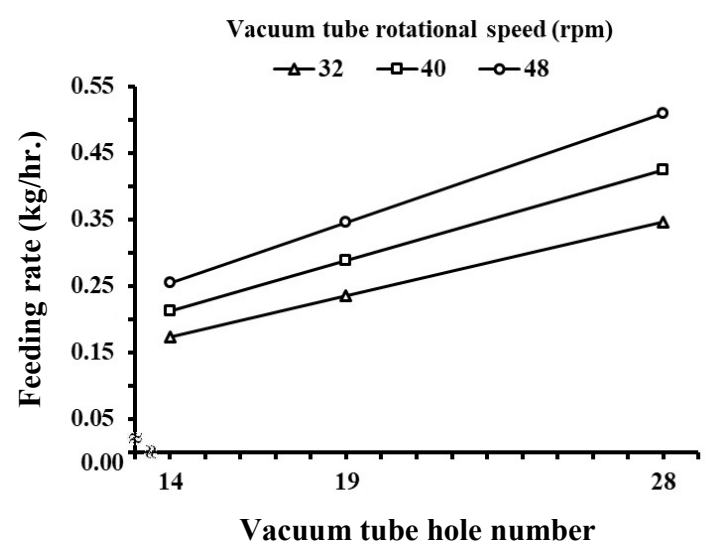

at forward speed of $1.45 \mathrm{~km} / \mathrm{hr}$.

Fig. 3. Effect of vacuum tube hole number on the feeding rate of dill seeds under different vacuum tube rotational speeds at different forward speeds

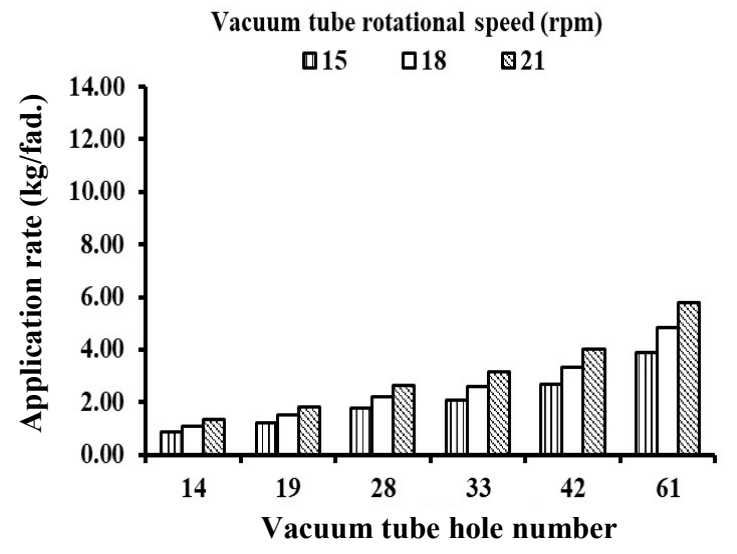

at forward speed of $0.65 \mathrm{~km} / \mathrm{hr}$.

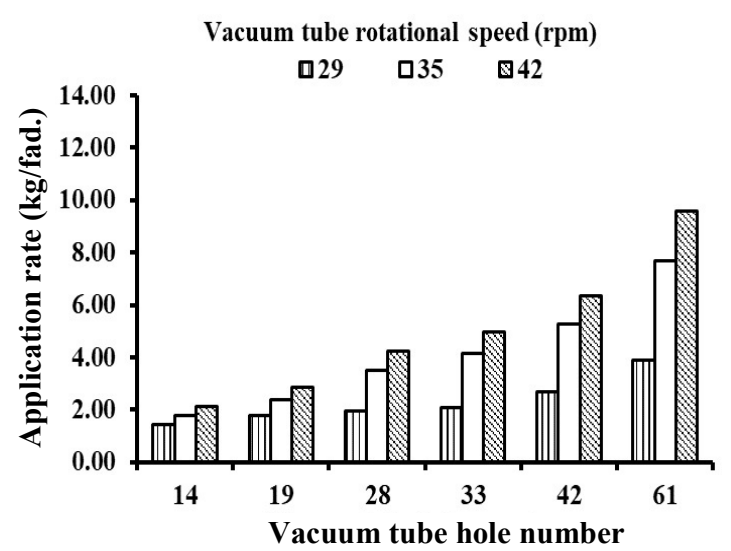

at forward speed of $1.03 \mathrm{~km} / \mathrm{hr}$.

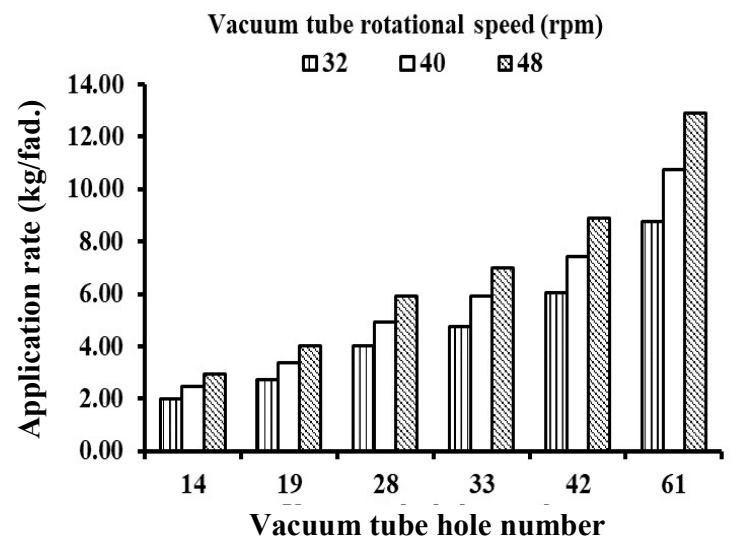

at forward speed of $1.45 \mathrm{~km} / \mathrm{hr}$.

Fig. 4. Effect of vacuum tube rotational speed and vacuum tube hole number on the application rate of dill seeds at different forward speeds 
Ahmad, et al.

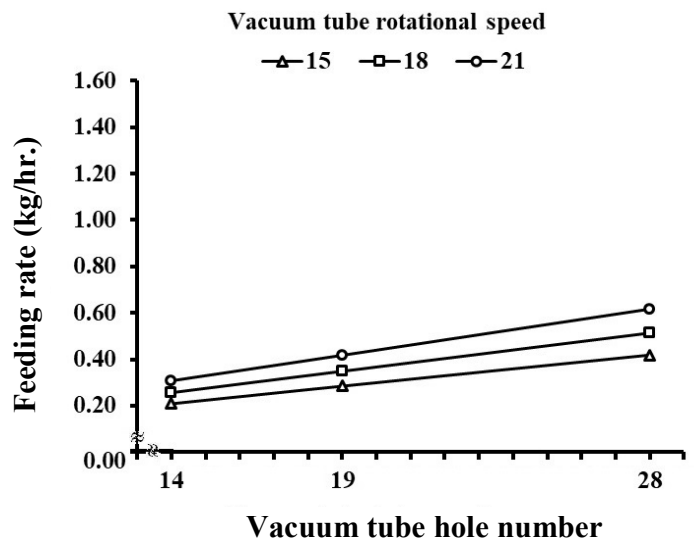

at forward speed of $0.65 \mathrm{~km} / \mathrm{hr}$.

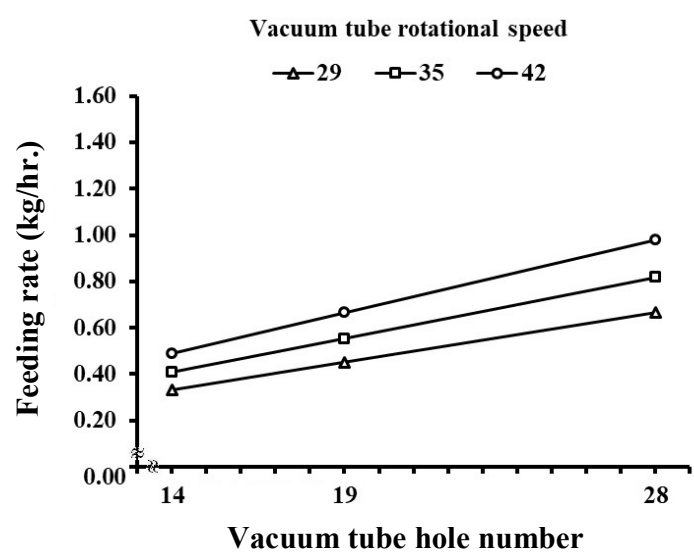

at forward speed of $1.03 \mathrm{~km} / \mathrm{hr}$.

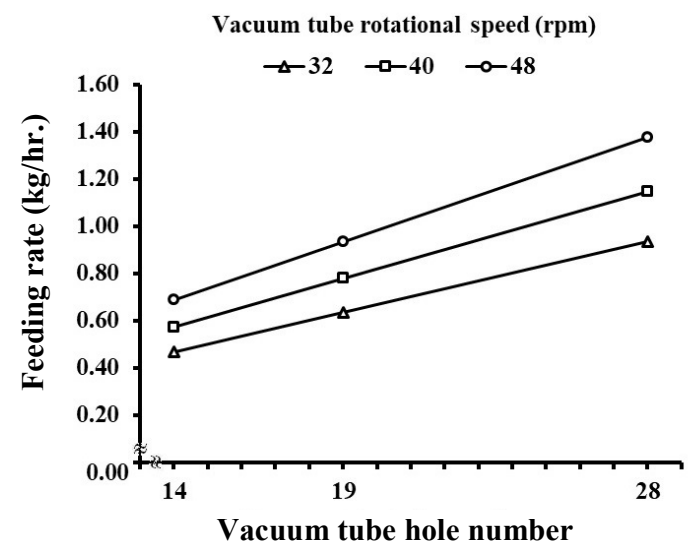

at forward speed of $1.45 \mathrm{~km} / \mathrm{hr}$.

Fig. 5. Effect of vacuum tube hole number on the feeding rate of coriander seeds under different vacuum tube rotational speed at different forward speeds

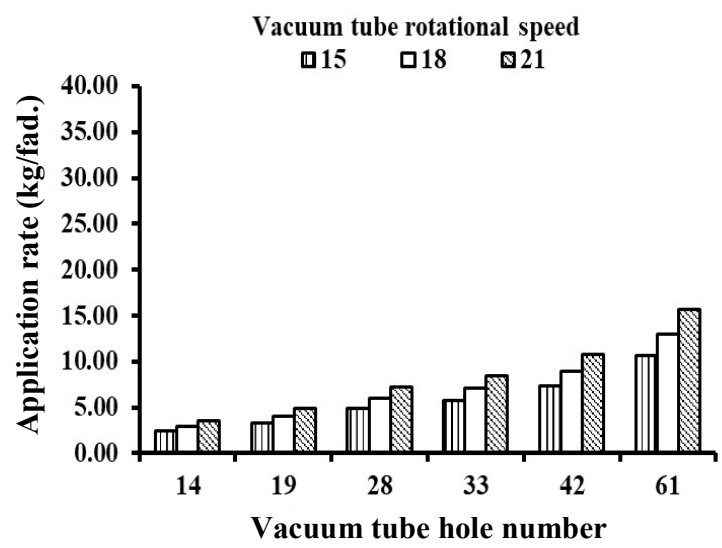

at forward speed of $0.65 \mathrm{~km} / \mathrm{hr}$.

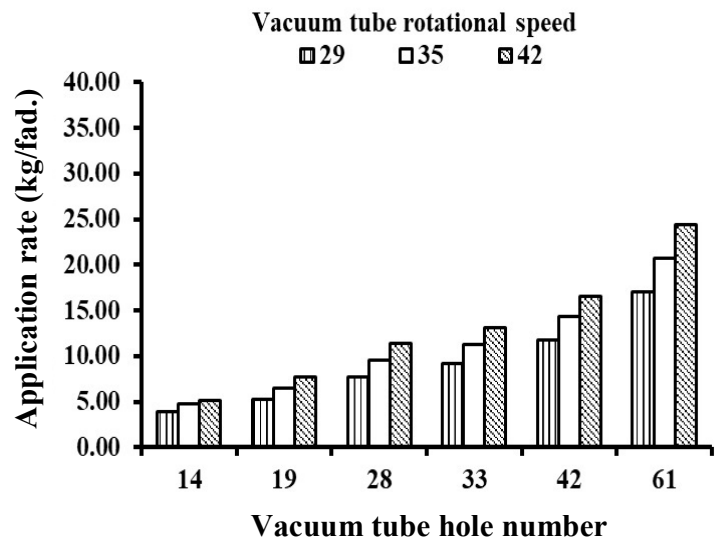

at forward speed of $1.03 \mathrm{~km} / \mathrm{hr}$.

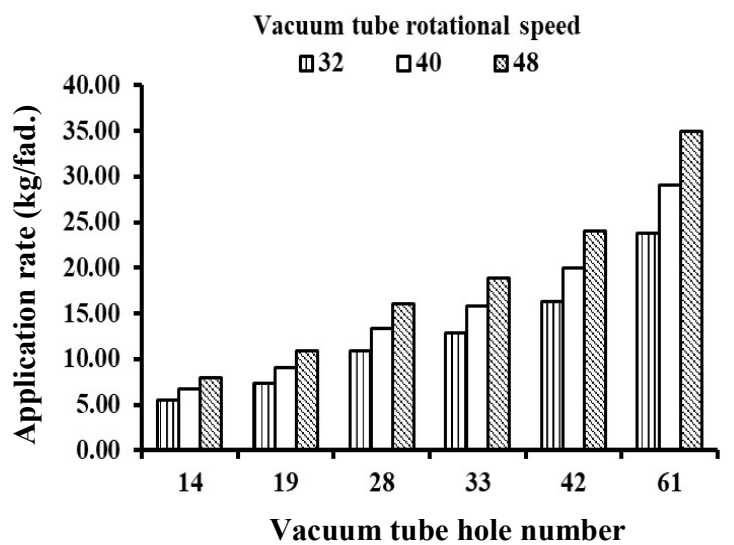

at forward speed of $1.45 \mathrm{~km} / \mathrm{hr}$.

Fig. 6. Effect of vacuum tube rotational speed and vacuum tube hole number on the application rate of coriander seeds at different forward speeds 
different hole number of a vacuum tube metering device on the application rate of coriander seeds at forward speed of $0.65 \mathrm{~km} / \mathrm{hr}$. The results indicated that, the application rate of dill seeds increases from 2.442 to 3.589 , from 3.322 to 4.867 , from 4.886 to 7.200 , from 5.764 to 8.474 , from 7.328 to 10.798 and from 10.65 to $15.674 \mathrm{~kg} / \mathrm{fad}$., by increasing in rotational speed of a vacuum tube metering device from 15 to $21 \mathrm{rpm}$., under holes numbers of $14,19,28$, 33, 42 and 61 holes, respectively. While, at forward speed of $1.03 \mathrm{~km} / \mathrm{hr}$., Fig. 6 indicated that, by increasing of rotational speed of a vacuum tube metering device from 29 to 42 rpm., the application rate of coriander seeds increases from 3.966 to 5.166 , from 5.272 to 7.752 , from 7.764 to 11.424 , from 9.238 to 13.098, from 11.730 to 16.590 and from 17.00 to $24.342 \mathrm{~kg} / \mathrm{fad}$., under the same previous conditions. Too, at forward speed of 1.45 $\mathrm{km} / \mathrm{hr}$., Fig. 6 referring to, at increasing rotational speed of a vacuum tube metering device from 32 to $48 \mathrm{rpm}$., the application rate of coriander seeds increased from 5.452 to 8.016, from 7.404 to 10.882 , from 10.906 to 16.048 , from 12.856 to 18.898 , from 16.358 to 24.064 and from 23.762 to $34.946 \mathrm{~kg} /$ fad., under the same previous conditions.

\section{Field Results}

Effect of different planting methods on the
uniformity of plant distribution at
longitudinal direction for dill and
coriander crops

Reults in Table 5 show the effect of the developed planter and manual planting on the uniformity of plant distribution for dill and coriander in the field at the longitudinal direction. Values of the coefficient of variation $(\mathrm{CV} \%)$ with the developed planter were 11.75 and $5.97 \%$ for dill and coriander plants, respectively. While with manual planting the values of the coefficient of variation were 34.67 and $27.73 \%$ for dill and coriander plants, respectively.

The results showed that, the lowest value of (CV\%) was obtained by the developed planter with coriander plants comparing with the dill plants. The main reason for this difference is attributed to the different morphological shape of the seed, where it was in the form of spherical seed in coriander and in the form of rectangle in dill.

The coefficient of variation under $10 \%$ is considered excellent, between $10-15 \%$ is good, between $15-20 \%$ is fair. While with value more than $20 \%$ is poor as reborted by (Coates, 1992). The uniformity of distribution with coriander using the developed planter is excellent, while with dill is good. But, the (CV\%) of the manual planting was poor (unacceptable), because, these value increased above (CV-20\%).

\section{Effect of different planting methods on some characteristics of dill and coriander plants}

The planting methods have a great effect on the plant features such as germination ratio and plants population. Results in Table 6 show that, the maximum germination ratio of 67 and $65 \%$ were remarked under the developed planter with coriander and dill, respectively. While the decreased value of the germination ratio to 56 and $53 \%$ under the manual planting with coriander and dill, respectively. Referring to the plants population, results in Table 6 show that, the highest number of plants per $\mathrm{m}^{2}$ of 93 and 86 plants $/ \mathrm{m}^{2}$ were obtained under planting method of the developed planter with dill and coriander, respectively. While, the decrease value numbers of plants per $\mathrm{m}^{2}$ of 73 and 77 plants $/ \mathrm{m}^{2}$ recorded under manual planting method with coriander and dill, respectively. This is due to variation in the accuracy of seed cover with soil in both planting methods in addition to variation in deep seed for manual planting method.

\section{Field capacity and field efficiency for different planting methods}

Field capacity and filed efficiency significantly varies from one to another planting method. Table 7 showed that, the field capacity values were 0.20 and $0.016 \mathrm{fad} . / \mathrm{hr}$., for the developed planter and manual planting respectively. Meanwhile, the field efficiency values were 95.25 and $76.33 \%$ under the same previous conditions for dill. While the values of field capacity for coriander were 0.29 and 0.025 fad./hr., for the developed planter and manual planting respectively. Meanwhile, the field efficiency values were 95.35 and $87.6 \%$ under the same previous conditions. 
Table 5. Effect of different planting methods on the uniformity of plant distribution at longitudinal direction for dill and coriander crops

\begin{tabular}{|c|c|c|c|c|}
\hline \multirow[t]{3}{*}{ Item } & \multicolumn{4}{|c|}{ Planting method } \\
\hline & \multicolumn{2}{|c|}{ The developed planter } & \multicolumn{2}{|c|}{ Manual planting } \\
\hline & Dill & Coriander & Dill & Coriander \\
\hline Coefficient of variation (C.V \%) & 11.75 & 5.97 & 34.67 & 27.73 \\
\hline
\end{tabular}

Table 6. Effect of different planting methods on some plant characteristics for dill and coriander plants

\begin{tabular}{lcccccc}
\hline Item & \multicolumn{5}{c}{ Planting method } \\
\cline { 2 - 3 } & \multicolumn{2}{c}{ The developed planter } & & \multicolumn{2}{c}{ Manual planting } \\
\cline { 2 - 3 } \cline { 5 - 6 } & \multicolumn{2}{c}{ Dill } & Coriander & & Dill & Coriander \\
\hline Germination ratio (\%) & 65 & 67 & & 53 & 56 \\
Number of plants per $\left(\mathbf{m}^{2}\right)$ & 93 & 86 & & 77 & 73 \\
\hline
\end{tabular}

Table 7. Field capacity and field efficiency for different planting methods for dill and coriander crops

\begin{tabular}{lcccccc}
\hline Item & \multicolumn{4}{c}{ Planting method } \\
\cline { 2 - 3 } & \multicolumn{2}{c}{ The developed planter } & & \multicolumn{2}{c}{ Manual planting } \\
\cline { 2 - 3 } \cline { 5 - 6 } & Dill & Coriander & & Dill & Coriander \\
\hline Field capacity (fad./hr.) & 0.20 & 0.29 & & 0.016 & 0.025 \\
Field efficiency (\%) & 95.25 & 95.35 & & 76.33 & 87.60 \\
\hline
\end{tabular}

Effect of different planting methods on Fresh and seed yield for dill and coriander crops

Both the fresh and seed yield of dill and coriander is greatly affected by the two planting methods. Results in Table 8 show that, the high average of green yield values for three cutting were 8.175 and $6.775 \mathrm{Mg} / \mathrm{fad}$., with dill crop under the developed planter and manual planting, respectively. While, the high average of seed yield values was 0.317 and 0.297 $\mathrm{Mg} / \mathrm{fad}$., under the same previous conditions. Too, the high average of seed yield values of coriander crop was 0.975 and $0.935 \mathrm{Mg} /$ fad., under the same previous conditions.
Total demand energy for planting methods of dill and coriander crops

The total demand energy of developed planter and manual planting for sowing dill and coriander crops were indicated in Table 9 the average values of Mechanical energy for planting dill and coriander by developed planter were 28.98 and $19.99 \mathrm{~kW} . \mathrm{hr}$./fad., while this values of human energy with manual planting were 22.2 and 14.21 under the same previous conditions. The variations in energy requirements with different planting methods is due to different soil resistance, soil reaction and rolling resistance against wheel. It is clear that the developed machine required the heights total 
Table 8. Effect of different planting methods on fresh and fresh yield for dill and coriander crops

\begin{tabular}{lcccccc}
\hline Item & \multicolumn{4}{c}{ Planting method } \\
\cline { 2 - 3 } & \multicolumn{2}{c}{ The developed planter } & & \multicolumn{2}{c}{ Manual planting } \\
\cline { 2 - 3 } \cline { 6 - 7 } & Dill & Coriander & & Dill & Coriander \\
\hline Fresh yield (Mg/fad.) & 8.175 & - & & 6.775 & - \\
Seed yield (Mg/fad.) & 0.317 & 0.975 & & 0.297 & 0.935 \\
\hline
\end{tabular}

Table 9. The total demand of energy and the actual demands of energy under different planting methods for dill and coriander crop

\begin{tabular}{|c|c|c|c|c|}
\hline \multirow[t]{3}{*}{$\overline{\text { Item }}$} & \multicolumn{4}{|c|}{ Planting method } \\
\hline & \multicolumn{2}{|c|}{ The developed planter } & \multicolumn{2}{|c|}{ Manual planting } \\
\hline & Dill & Coriander & Dill & Coriander \\
\hline$\overline{\text { Forward speed (km/hr.) }}$ & 1.45 & 1.45 & $\begin{array}{c}------ \\
\end{array}$ & 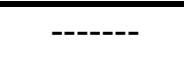 \\
\hline Fuel consump (L/hr.) & 1.54 & 1.54 & ------- & ------- \\
\hline Number of the laborers & 1 & 1 & 8 & 8 \\
\hline Actual field capacity (fad./hr.) & 0.20 & 0.29 & 0.016 & 0.025 \\
\hline Human energy (kW.hr./fad.) & 2.775 & 1.776 & 22.2 & 14.21 \\
\hline Mechanical energy (kW.hr./fad.) & 28.98 & 19.99 & ------- & ------- \\
\hline Total demand energy (kW.hr./fad.) & 31.755 & 21.77 & 22.2 & 14.21 \\
\hline
\end{tabular}

demand of energy 31.755 and $21.77 \mathrm{~kW} . \mathrm{hr} . /$ fad., for planting dill and coriander, respectively. While for manual planting the total demand of energy values were 22.2 and $14.21 \mathrm{~kW} . \mathrm{hr} . / \mathrm{fad}$. ., under the same previous conditions.

Cost analysis for planting methods of dill and coriander crops

The cost of field machinery is dependent on many factors due to the planter conditions and the mechanization system. Results in Table 10 represents the cost per fad., for different planting methods. In the dill crop, the manual planting required the heights cost $520.63 \mathrm{LE} /$ fad., while the developed planter required $211.25 \mathrm{LE} /$ fad. Too, in the coriander crop, the manual planting required the heights cost $333.2 \mathrm{LE} /$ fad., while the developed planter required $145.69 \mathrm{LE} / \mathrm{fad}$. Results in Table 10 represent the cost per unit of production for different planting methods of dill and coriander crops. The cost of total fresh and seed yield production per $\mathrm{Mg}$ can be arranged in descending order of manual planting and developed planter, respectively. On the developed planter recorded the lowest value per unit production 24.88 and $149.43 \mathrm{LE} /$ fad., respectively.

\section{Conclusion}

From the obtained results, it is recommended to use a developed planter for planting dill and coriander crops to ensure more uniformity of seed distribution in row, higher crop yield, minimum cost and energy requirements under operational conditions including number of hole of feeding device of 14 holes, velocities of feeding device of $32 \mathrm{rpm}$ and forward speed of $1.45 \mathrm{~km} / \mathrm{hr}$. 
Table 10. Operational cost and cost per unit of production under different planting methods for dill and coriander crop

\begin{tabular}{lcccccc}
\hline Item & \multicolumn{4}{c}{ Planting method } \\
\cline { 2 - 3 } & \multicolumn{2}{c}{ The developed planter } & & \multicolumn{2}{c}{ Manual planting } \\
\cline { 2 - 3 } \cline { 6 - 7 } & Dill & Coriander & & Dill & Coriander \\
\hline Actual field capacity (fad./hr.) & 0.20 & 0.29 & & 0.016 & 0.025 \\
Hourly cost (LE/hr.) & 42.25 & 42.25 & & 8.33 & 8.33 \\
Operational cost (LE/fad.) & 211.25 & 145.69 & & 520.63 & 333.2 \\
Total fresh and seed yield (Mg/fad.) & 8.492 & 0.975 & & 7.072 & 0.935 \\
Cost per unit of production (LE/fad.) & 24.88 & 149.43 & & 73.62 & 356.36 \\
\hline
\end{tabular}

\section{REFERENCES}

Adisa, A.F. (2012). Design and development of template row planter. Trans. J. Sci. and Technol., 2 (7): 27 - 31.

Coates, W. (1992). Performance evaluation of a pendulum spreader. Trans. ASAE, 8 (3): 285 -288 .

FAO Statistical Year Book (2017). World food and agriculture, Food and Agriculture Organization of the United Nations, Econ. and Soc. Dev. Dept., Roma.

Hunt, D. (1983). Farm power and machinery management Eighth edition, Iowa state Univ., Press Ames, USA. Ames, Iowa, USA: $364-368$.

Kamel, O.M., M. El-Iragi and M. Metwaly (2003). Operating factors affecting using pneumatic seed drill for sowing wheat. Misr J. Ag. Eng., 20 (3): 767 - 782.
Karayel, D. and A. Ozmerzi (2002). A research on the use of a precision vacuum seeder unit for hill-drop sowing. Eighth International Congress on Mechanizations and Energy in Agriculture. Izmir, Turkey, kusadasi-Turkey, $351-355$.

Megbowon, I.O. and S.O. Adewunmi (2002). Effect of failure of NEPA electricity on the finance of small and medium scale industries: case study of two agro-allied industries in Ondo State. Nigerian J. Indust. Safety and Systems, 1(1): 28 - 31

Morad, M.M., M. Afifi, H.M. Hekal and E.E. Abd El-Aty (2010). Development of a planting machine used under Sub-surface irrigation system, Misr J. Ag. Eng., 27 (4) : 945 - 979.

Shaaban, Y.A. (2010). Development of An appropriate pneumatic planter for small holdings in Egypt. Ph.D. Thesis, Agric. Eng. Dep., Coll. Agric. at Moshtohor, Benha Univ., Egypt. 


\title{
تطوير وتقييم أداء جهاز تلقيم دقيق يعمل بشفط الهواء يناسب زراعة المحاصيل الطبية والعطرية
}

\author{
علا طه الأحمدى أحمد' ـ محمد محمد مراد' ـ محمود مصطفى على' ـ محمد حمزه أبو النجاج

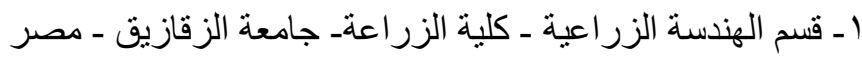

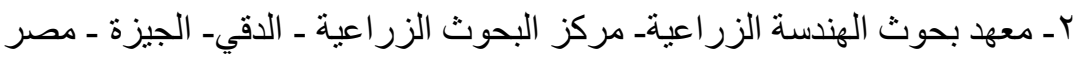

يهدف هذا البحث إلى تطوير جهاز تلقيم يعمل بشفط الهواء لزر اعة كلا من بذور الثبت و الكزبرة، حيث تم تطوير

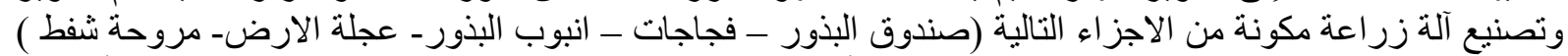

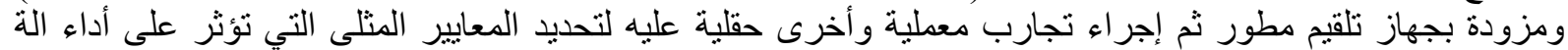

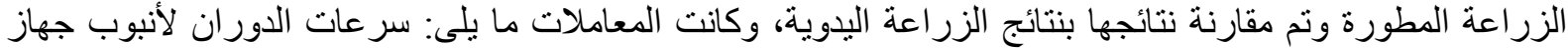

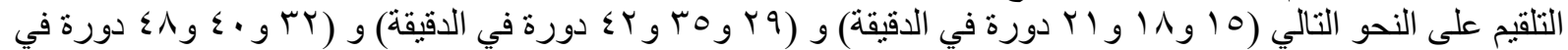

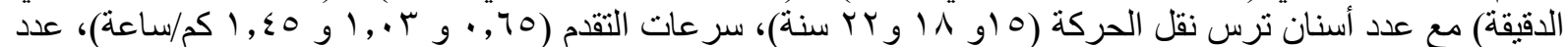

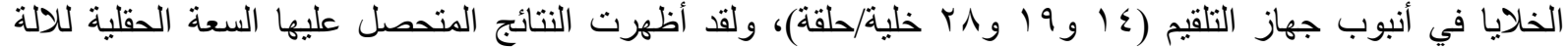

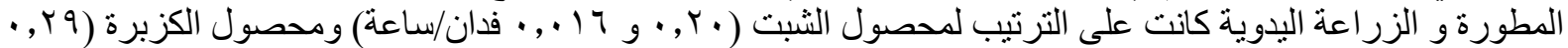

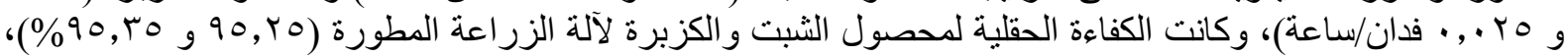

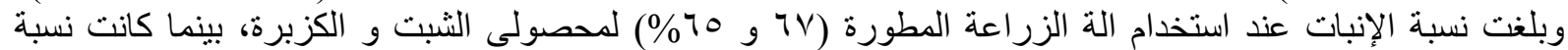

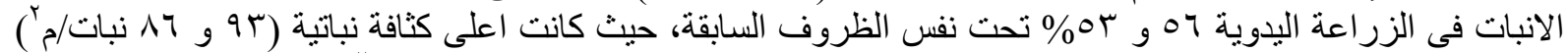

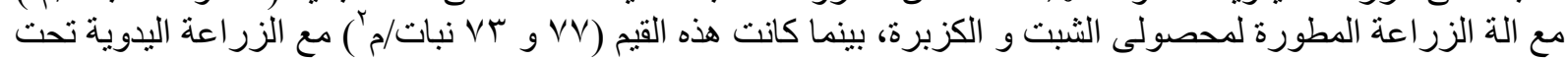

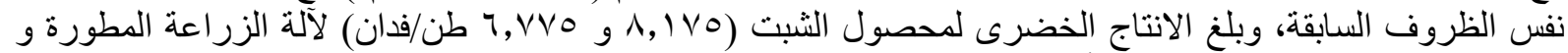

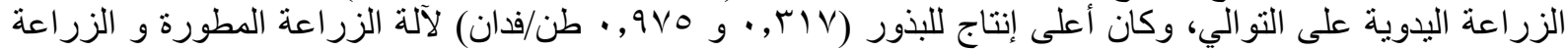

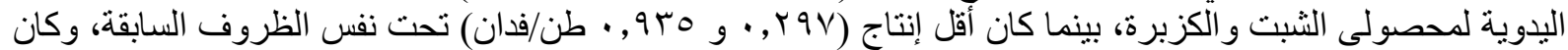

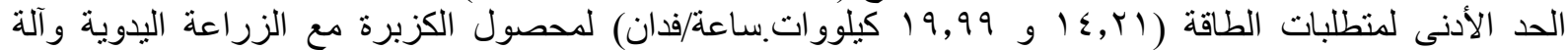

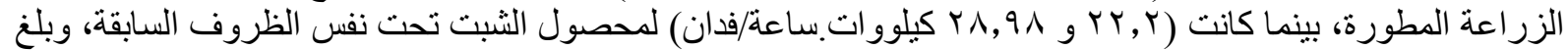

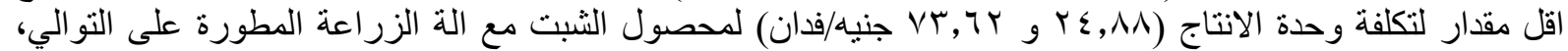

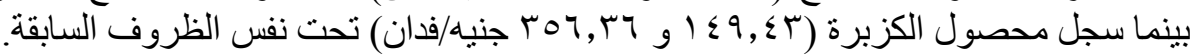

أستاذ الهندسة الزر اعية - كلية الزر اعة - جامعة دمياط. أستاذ الهنسة الزر اعية المنفرغ غل - كلية الزر اعة - جامعة الزقازيق. 